Archive for

Organic Chemistry

Arkivoc 2020, part vii, 401-421

\title{
Trisubstituted push-pull nitro alkenes
}

\section{Branislav Pavilek* and Viktor Milata}

Institute of Organic Chemistry, Catalysis, and Petrochemistry, Faculty of Chemical and Food Technology, Slovak University of Technology, Radlinského 9, SK-812 37 Bratislava, Slovakia

Email: Brano.Pavilek@gmail.com

\section{Dedicated to Professor Jan Bergman on the occasion of his 80th birthday.}

Received 02-18-2021

Accepted 04-19-2021

Published on line $04-30-2021$

\section{Abstract}

Properties, preparations, and utilization in the organic synthesis of the trisubstituted push-pull nitroalkenes are summarized from all the relevant results published until 2020. Preparation of these nitroalkenes is versatile due to numerous of the starting materials. The importance of reviewed nitroalkenes is outlined by their frequent exploitation in the synthesis of biologically active compounds, as well as a vast range of heterocyclic derivatives.

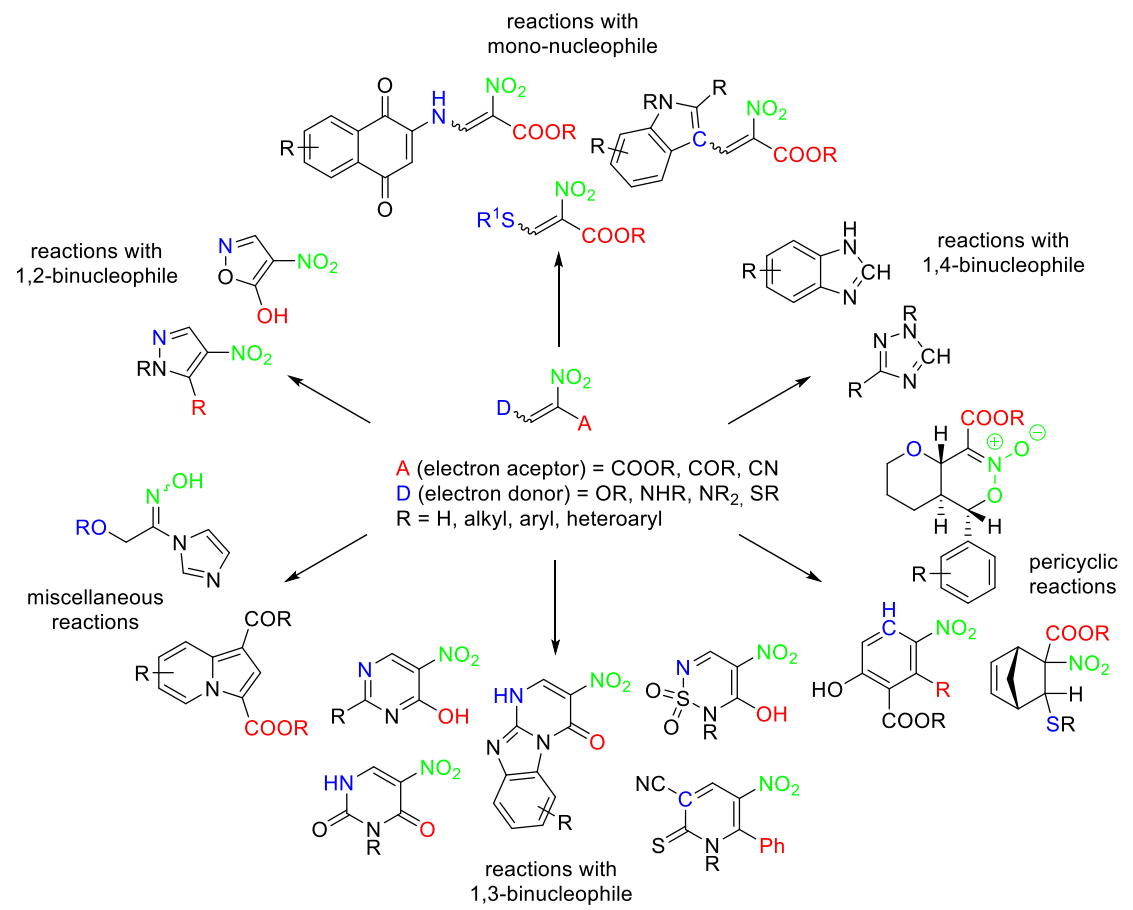

Keywords: Push-pull nitroalkenes, nucleophilic vinylic substitution, heterocycles formation, nitroalkenes cycloadditions 


\section{Table of Contents}

1. Introduction

2. Review

2.1. Isomerism

2.2. Preparation

2.2.1. Formation of nitroenolethers $(A)$

2.2.2. Formation of mono- $N$-substituted nitroenamines (B)

2.2.3. Formation of di- $N, N$-substituted nitroenamines (C)

2.2.4. Other preparations (D)

2.3. Utilization in organic synthesis

2.3.1. Reactions with mono-nucleophiles (E)

2.3.2. Reactions with 1,2-binucleophiles (F)

2.3.3. Reactions with 1,3-binucleophiles (G)

2.3.4. Reactions with 1,4-binucleophiles $(\mathrm{H})$

2.3.5. Pericyclic reactions $(\mathrm{J})$

2.3.6. Miscellaneous utilization in organic synthesis $(\mathrm{K})$

3. Conclusions

\section{Introduction}

Conjugated nitro compounds are versatile, useful, and often employed as a building block in organic synthesis. ${ }^{1-3}$ Due to their conjugated nature, they can act as electrophiles in 1,4- or 1,2-additions with nucleophiles or radicals, respectively. They can be also exploited as dienophiles or heterodienes in the DielsAlder reaction. In recent years, their importance has been enhanced by utilization in asymmetric synthesis. ${ }^{4}$ Furthermore, the nitro group can be transformed into a variety of other functional groups. ${ }^{5}$ Some of the most important transformations are conversion of primary or secondary nitro compounds into aldehydes or ketones, known as the Nef reaction. ${ }^{6}$ Reduction of a nitro group into an amino group is one of the most utilized catalytic processes in the fine and bulk chemical industry, and it can be achieved by various combinations of the hydrogen source and catalyst. The hydrogen source is usually molecular hydrogen, and the catalyst can be different metals. ${ }^{7}$ Replacement of the nitro group with hydrogen, commonly referred to as denitration is generally carried out via a radical process using tin hydride. ${ }^{8}$ A special place of nitro olefins in organic synthesis is underlined by many articles, reviews, and books dedicated to them. ${ }^{9-11}$ Despite this vast literature base, there are just very few papers dedicated to polysubstituted nitro alkenes, their preparation, and their utilization in organic synthesis. Trisubstituted push-pull nitro alkenes are one of the most important compounds of such omitted nitro alkenes group (Figure 1). Disubstituted push-pull nitro alkenes (without another electron acceptor A) undergo formations of heterocycles worse than trisubstituted nitroalkenes as another electron acceptor $A$ can readily react in nucleophilic additions with 1,2-12 or 1,3-binucleophiles ${ }^{13,14}$ and nitro group cannot offer such a reaction. The preparation of tetrasubstituted nitroalkenes is less convenient than trisubstituted nitroalkenes in terms of yields, a number of methods, reaction times, temperatures, and toxicity of required reagents. ${ }^{1}$ 
<smiles>[2H]C=C([Tl])[N+](=O)[O-]</smiles>

A (electron aceptor) $=$ acyl, cyano, carboxylic acid derivatives

$\mathrm{D}$ (electron donor) $=$ acyclic moiety linked via heteroatom to double bond

Figure 1. The general structure of trisubstituted push-pull nitro alkenes.

The value of this group of compounds can be demonstrated by their utilization as a reagent in the synthesis of biologically active compounds over the years. ${ }^{14-20}$ For instance, they have been used in rational drug design of topically administered caspase 1 inhibitors for the treatment of inflammatory acne, ${ }^{14}$ in the synthesis and biological evaluation of pyrimidine derivatives as novel human Pin1 inhibitors in the cancer treatment, ${ }^{15}$ and the preparation of scaffolds for the design of Rac1-Tiam1 protein-protein interaction inhibitors ${ }^{16,17}$. Title compounds were also employed in the synthesis of alkaloid meridianin $\mathrm{G}^{18}$ and the synthesis of the insect feeding deterrent peramine. ${ }^{19}$ In the most recent article, they are utilized in the synthesis of 2-imidazopyridine and 2-aminopyridone purinones as potent Pan-Janus kinase (JAK) inhibitors for the inhaled treatment of respiratory diseases. ${ }^{20}$

\section{Review}

\subsection{Isomerism}

Trisubstituted alkenes may exist as single E/Z-isomers or they can undergo isomerization between these two structures. Detailed IR and NMR studies for the structure with $A=$ ester and $D=$ amino group were performed to determine $E / Z$-ratios and the existence of predominant isomer. ${ }^{21}$

Based on previous studies authors established 3 possible isomers for reviewed molecules. Z-isomers differ due to the conformation of the carbonyl group toward double bond (Figure 2).

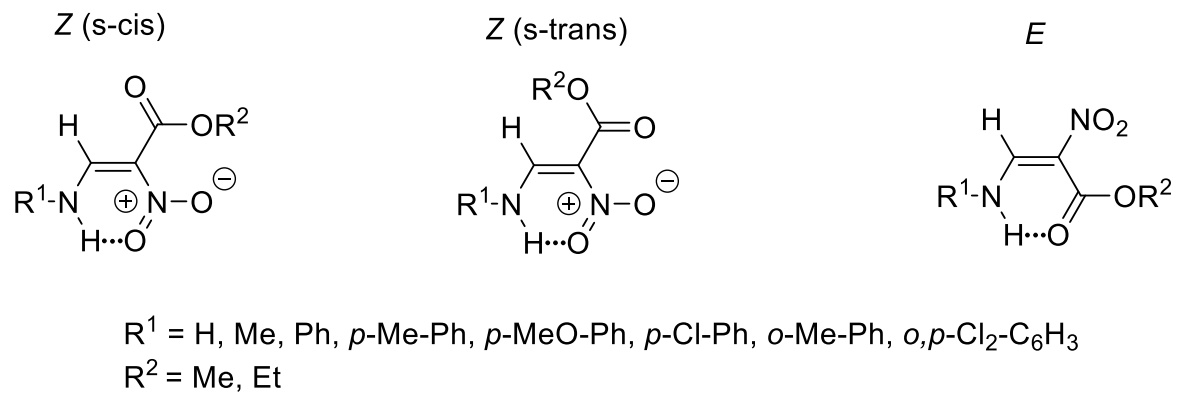

Figure 2. Confirmed E/Z-isomers of reviewed structures.

The authors confirmed the presence of all three isomers and established $E / Z$ ratios based on the correlation of ${ }^{1} \mathrm{H},{ }^{13} \mathrm{C} N M R$, and IR spectra. From these results they concluded that (i) substrates crystallize as one of those isomers, however, they may isomerize even in the solid state. (ii) In the solution, a mixture of $E / Z$-isomers is readily formed. Formed equilibrium is dependent on the polarity of the solvent and strength of the hydrogen bond between $\mathrm{H}$ from amino group and $\mathrm{O}$ from carbonyl or nitro group, respectively. (iii) Z- 
isomer has been predominant in many measured substrates, which is the most substantial difference of 3amino-2-nitroacrylic esters from 3-aminoacrylic esters and nitroenamines. The abundance of Z-isomer in the mixture correlates with its stronger hydrogen bond between $\mathrm{H}$ from amino and $\mathrm{O}$ from the nitro group (Table 1).

Table 1. Results concluded from key IR, NMR spectral data, and two-bond deuterium isotope effect on C-3 chemical shifts. Modified from the table $\mathrm{e}^{21}$

\begin{tabular}{|c|c|c|c|c|}
\hline compound & solvent & $E / Z$ & ${ }^{2} \Delta / E_{H}(E-i s o m e r)^{a}$ & ${ }^{2} \Delta / E_{H}(\text { Z-isomer })^{a}$ \\
\hline $\mathrm{Me}-\mathrm{NH}_{\mathrm{s}}^{-\mathrm{NO}_{2}}<_{\text {CoOMe }}^{\mathrm{N}_{2}}$ & 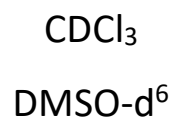 & $\begin{array}{c}52 / 48 \\
-\end{array}$ & $170 / 6,6$ & $179 / 6,8$ \\
\hline $\mathrm{Ph}-\mathrm{NH}=\mathrm{CoOMe}_{\text {come }}$ & $\begin{array}{c}\mathrm{CDCl}_{3} \\
\text { DMSO-d }\end{array}$ & $\begin{array}{l}43 \text { / } 57 \\
33 \text { / } 67\end{array}$ & $236 / 7,6$ & $259 / 7,8$ \\
\hline $\begin{array}{l}\mathrm{NO}_{2} \\
\mathrm{COOMe}\end{array}$ & $\begin{array}{c}\mathrm{CDCl}_{3} \\
\mathrm{DMSO}^{6} \mathrm{~d}^{6}\end{array}$ & $\begin{array}{l}50 / 50 \\
39 / 61\end{array}$ & $233 / 7,5$ & $248 / 7,7$ \\
\hline $\begin{array}{l}\mathrm{NO}_{2} \\
\text { COOMe }\end{array}$ & $\begin{array}{c}\mathrm{CDCl}_{3} \\
\text { DMSO-d }^{6}\end{array}$ & $\begin{array}{l}54 / 46 \\
40 / 60\end{array}$ & $235 / 7,6$ & $240 / 7,6$ \\
\hline $\begin{array}{l}\mathrm{NO}_{2} \\
\mathrm{COOMe}\end{array}$ & $\begin{array}{c}\mathrm{CDCl}_{3} \\
\text { DMSO-d }\end{array}$ & $\begin{array}{l}43 / 57 \\
40 / 60\end{array}$ & $244 / 7,7$ & $256 / 7,8$ \\
\hline${ }_{\text {coome }}^{\mathrm{NO}_{2}}$ & $\begin{array}{c}\mathrm{CDCl}_{3} \\
\text { DMSO-d }\end{array}$ & $\begin{array}{l}45 / 55 \\
37 / 63\end{array}$ & $235 / 7,6$ & $247 / 7,7$ \\
\hline $\int_{-\mathrm{NH}}^{\mathrm{Me}} \overbrace{\text { сооме }}^{\mathrm{NO}_{2}}$ & $\begin{array}{c}\mathrm{CDCl}_{3} \\
\mathrm{DMSO}^{6} \mathrm{~d}^{6}\end{array}$ & $\begin{array}{l}45 / 55 \\
37 / 63\end{array}$ & $236 / 7,6$ & $263 / 7,9$ \\
\hline
\end{tabular}

a Hydrogen bond enegies $\left(E_{\mathrm{H}} / \mathrm{kcal} \mathrm{mmol}^{-1}\right.$ ) were calculated from two-bond deuterium isotope effect on $\mathrm{C}-3$ chemical shifts $\left({ }^{2} \Delta /\right.$ p.p.b) according to equation ${ }^{2} \Delta=10^{3}\left[\delta_{\mathrm{C}-3}(\mathrm{NH})-\delta_{\mathrm{C}-3}(\mathrm{ND})\right] ; \ln \left({ }^{2} \Delta\right)=2.783+0.354 \mathrm{E}_{\mathrm{H}} \cdot{ }^{22,23}$ Values for ${ }^{2} \Delta$ were obtained in $\mathrm{CDCl}_{3}$ solution at $0.2 \mathrm{M}$ concentration.

Also, the rate constant of this isomerization was studied for the reviewed structures and their analogs (Figure 1). An effect of substituent $R$ and electron-withdrawing group $Z$ on the rate constant was investigated. ${ }^{24}$<smiles>[R]N/C=C(\[Z])C(=O)OCC</smiles>

Figure 1. Model structure for the study of the rate constant of isomerization. 
The authors estimated the free activation Gibbs Energy $\Delta G^{\neq}$for the double bond rotation from the coalescence data (Table 2) according to the modified Eyring equation.

Table 2. Main NMR parameters and estimated the free activation Gibbs Energy $\Delta G \neq$ for the double bond rotations for compounds with $\mathrm{Z}=\mathrm{NO} 2$ and $\mathrm{R}=\mathrm{H}, \mathrm{Ph}$. Modified from the table.24

\begin{tabular}{|c|c|c|c|c|}
\hline compound $^{\mathrm{a}}$ & observed signal & $\mathrm{T}^{\mathrm{b}}$ & $\Delta u^{c}$ & $\Delta \mathrm{G}^{\neq}(E / Z)^{\mathrm{d}}$ \\
\hline${ }_{\mathrm{H}-\mathrm{NH}}^{5-} \mathrm{NOOEt}_{\mathrm{NO}}^{\mathrm{NO}_{2}}$ & $\mathrm{CH}$ & $319 \pm 2$ & 40.0 & $60.8 / 68.2 \pm 1.0$ \\
\hline${ }_{\mathrm{Ph}-\mathrm{NH}}^{5=} \mathrm{NOOOEt}_{\text {COE }}^{\mathrm{NO}_{2}}$ & $\mathrm{CH}$ & $354 \pm 2$ & 43.0 & $74.1 / 75.8 \pm 1.0$ \\
\hline
\end{tabular}

${ }^{a}$ Compounds were measured in DMSO- $\mathrm{d}^{6}$ as $0.2-1 \mathrm{M}$ solutions; ${ }^{\mathrm{b}}$ coalescence temperature $\mathrm{T}_{\mathrm{C}}$ is in $\mathrm{K}$; ${ }^{c}$ the separation of the exchanging resonances at the low $\mathrm{T}$ limit $\Delta \mathrm{U}$ is in $\mathrm{Hz} ;{ }^{\mathrm{d}} \Delta \mathrm{G}^{\neq}$is in $\mathrm{kJ} \mathrm{mol}{ }^{-1}$.

They expected and confirmed a thermal isomerization mechanism. Substituents, that stabilize the formed charges on the carbons $\mathrm{C} 2$ and $\mathrm{C} 3$ by the delocalizing negative charge on the $\mathrm{C} 2$ or donating electrons to electron deficit C3 (Figure 2) will lower the rotation barrier.

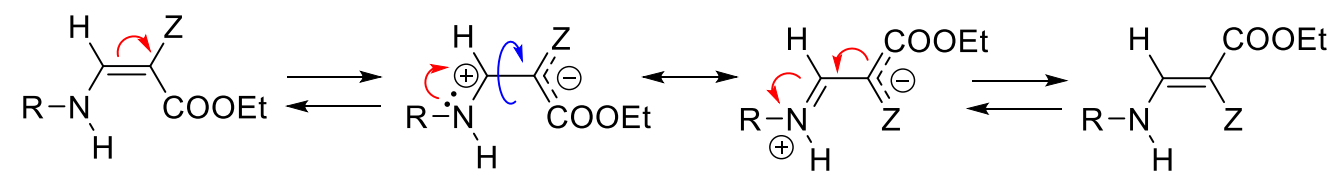

Figure 2. Double bond rotation between $E / Z$ isomers by thermal isomerization mechanism.

The comparison of the rotation barrier with regard to the substituent $\mathrm{R}$ on the donor amino group results in the sequence $\mathrm{Ph}>\mathrm{H}>$ Et. This correlation was confirmed by measurement for all the substrates except $\mathrm{Z}=$ $\mathrm{CN}$. The lowest barrier of the rotation has substrates with $\mathrm{R}=\mathrm{Et}$ due to the $\mathrm{I}+$ effect of this group.

The comparison of the rotation barrier with regard to the acceptor substituents $Z$ results in the sequence $\mathrm{CN}>\mathrm{COOR}>\mathrm{COMe}>\mathrm{NO}_{2}$. This correlation was confirmed by measurement for all the substrates except $\mathrm{R}=$ $\mathrm{Ph}$. The lowest barrier of the rotation has substrates with $\mathrm{Z}=\mathrm{NO}_{2}$ due to the strong $\mathrm{M}$ - and I- effect of this group.

\subsection{Preparation}

Frequently used synthetic routes to obtain reviewed structures can be divided into four groups (Scheme 1-5).

2.2.1. Formation of nitroenolethers $(A)$. The first method $A$ (Scheme 1 ) is the most exploited preparation of reviewed structures of nitroenolethers where ether alkyl is mostly lower alkyl (methyl, ethyl). ${ }^{12,16,17,19,25-32}$ The reaction of ethyl orthoformate and acetic anhydride with active methylene compounds was reported by Claisen ${ }^{33}$ in 1893. The modification ${ }^{28}$ for alkyl nitroacetates was first time reported in 1959. 


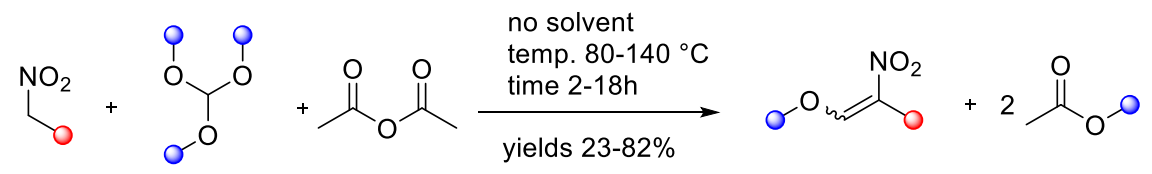

Method is described in 12 papers ${ }^{12,16,17,19,25-32}$ and it is utilized to prepare aprox. 9 derivatives

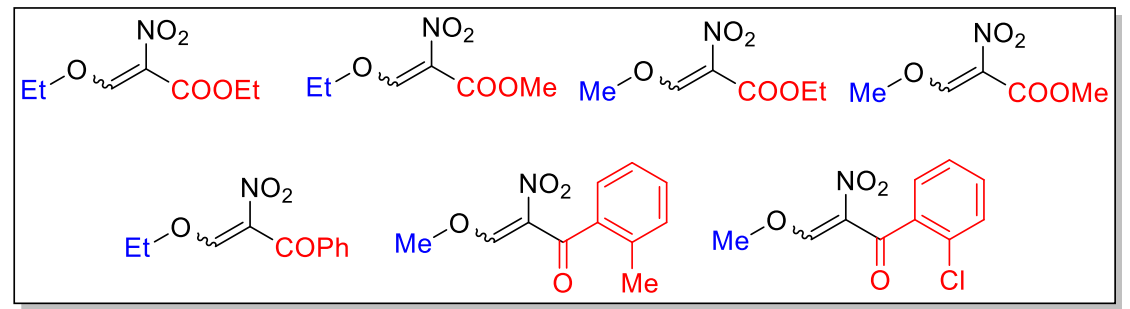

$\mathrm{O}=$ acyl, methyl $/$ ethyl ester group

$\mathrm{O}=$ methyl, ethyl

Scheme 1. The preparation of title nitroalkenes by method A.

A1<smiles>CC(=O)OC(C)=O</smiles><smiles>[R]OC([R])O[R]</smiles><smiles>C=C</smiles>

A2<smiles>[R]OC([R])OC(C)=O</smiles><smiles>CCOCCC(=O)[N+](=O)[O-]</smiles><smiles>C=C</smiles><smiles>[R]OC([R20])C(C(=O)OCC)[N+](=O)[O-]</smiles>

A3<smiles>[R]OC([R])C([N+](=O)[O-])[O+]([O-])OCC</smiles><smiles>C=C</smiles><smiles>[R6]C=C(C(=O)OCC)[N+](=O)[O-]</smiles>

A4<smiles>[R]O[CH-]C(C)=O</smiles><smiles>C1CCCC1</smiles><smiles>[R]OC(C)=O</smiles><smiles>CC(=O)O</smiles>

A5<smiles>[R]OC([R])OC(C)=O</smiles>

$\mathrm{R}=\mathrm{Me}, \mathrm{Et}$<smiles>[R]OC([R])OC(C)=O</smiles> 
2.2.2. Formation of mono- $\mathbf{N}$-substituted nitroenamines (B). Second method $B$ can be considered as an analog to method A for the preparation of 3-amino-substituted reviewed structures. ${ }^{14,28,34-38}$ The products 3-alkylamino2-nitroacrylic esters used to be prepared by nucleophilic vinylic substitution on 3-alkoxy-2-nitroacrylic esters with adequate $\mathrm{N}$-nucleophile. ${ }^{28}$ The paper $^{31}$ describing reactions with diverse groups of $\mathrm{N}$-nucleophiles and utilizing "one-pot" reaction pathway B depicted in (Scheme 3), was published in 1963. Authors there demonstrate formations of pyrimidone derivatives by subsequent reaction of alkyl nitroacetates, trialkyl orthoformate, and urea derivatives. This preparation of pyrimidones was previously known for the other compounds with active methylene group 39,40 and for the reviewed structures is described in more detail in chapter 2.3.3.

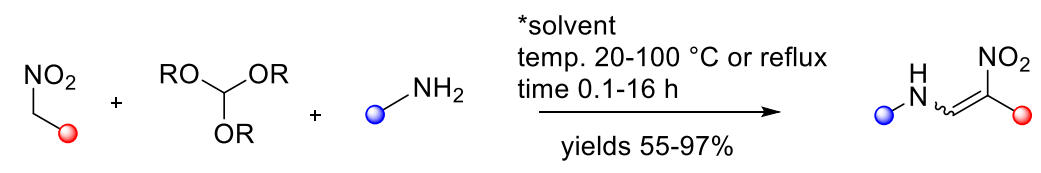

Method is described in 7 papers ${ }^{14,28,34-38}$ and it is utilized to prepare aprox. 15 derivatives

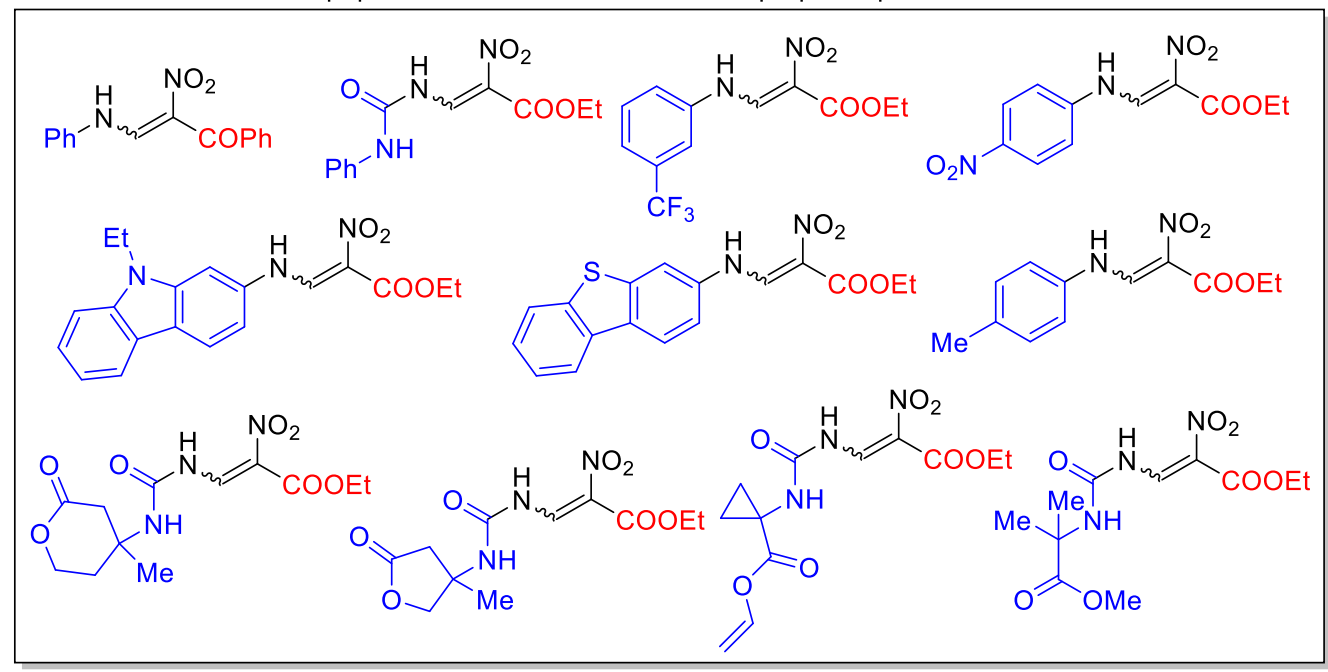

O = acyl, ester

$\mathrm{O}=$ alkyl, aryl, heteroaryl, $\mathrm{H}$

$\mathrm{R}=\mathrm{Me}, \mathrm{Et}$

*solvent $=$ no solvent $/$ toluene $/ \mathrm{MeOH} / \mathrm{EtOH} / \mathrm{AcOH}$

Scheme 3. The preparation of title nitroalkenes by method B.

The reaction pathway was suggested in the past just for the modification of method B with active methylene group compounds without a nitro group and urea derivatives. ${ }^{41} \mathrm{An}$ analogical reaction pathway can be expected for the reviewed structures.

2.2.3. Formation of di- $\mathbf{N}, \mathbf{N}$-substituted nitroenamines (C). Method $\mathrm{C}$ is used for the preparation of reviewed structures less frequently, although it has some advantages (e.g. a smaller number of starting components) in comparison with methods A and B. Dimethylformamide-dimethyl acetal serves as a source of a carbon atom instead of trialkyl orthoformate. Resulting $N, N$-dimethylamino nitroalkene contains a relatively good leaving group which may facilitate further nucleophilic reactions (Scheme 4). This method was mostly exploited for the preparation of reviewed structures with acyl group ${ }^{18,42-45}$ as the second electron-withdrawing group. 


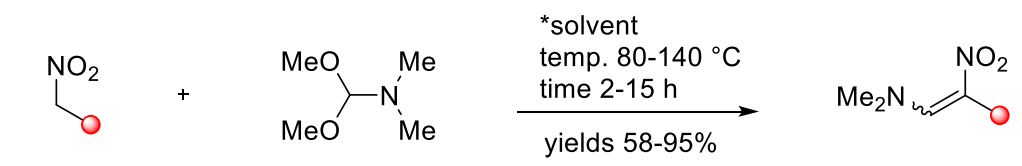

Method is dexcribed in 5 papers ${ }^{18,42-45}$ and it is utilized to prepare aprox. 6 derivatives

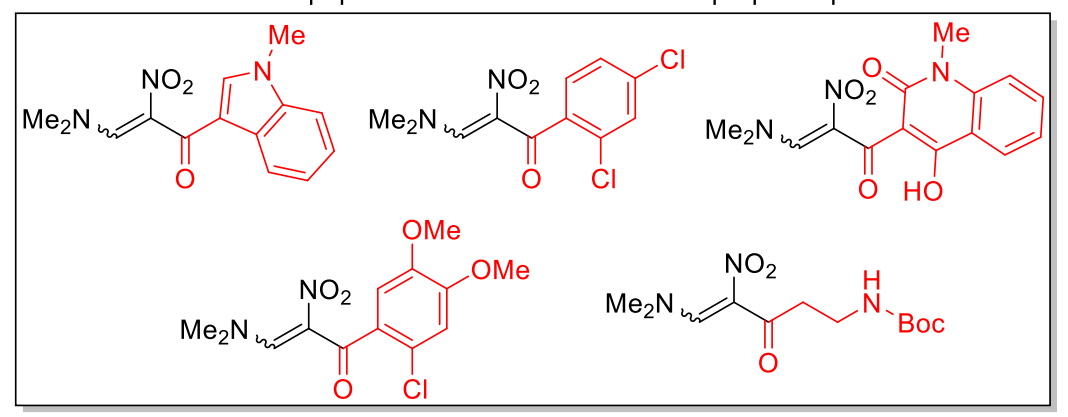

O = acyl group

*solvent $=$ no solvent $/ \mathrm{DCM} / \mathrm{THF} /$ toluene

Scheme 4. The preparation of title nitroalkenes by method C.

2.2.4. Other preparations (D). Last method $D$ is a group of the reactions, that does not fit any previous preparative approaches (Scheme 5). The first reaction D1 provides 3-amino-2-nitroacrylic ester from formamidine acetate and ethyl nitroacetate. ${ }^{33}$ The same product may be obtained in a stepwise manner by method A. Second reaction ${ }^{46}$ D2 exploits isocyanides due to their versatility and extensive utilization in $\mathrm{C}-\mathrm{H}$ functionalization reactions. ${ }^{47}$ The authors developed a radical coupling/isomerization strategy for the crosscoupling of isocyanides with active methylene compounds through silver-catalysis. The method solves the over-insertion of isocyanides ${ }^{48}$ and affords a variety of otherwise difficult to synthesize compounds. The authors also suggested a plausible mechanism of the reaction (Scheme 6).

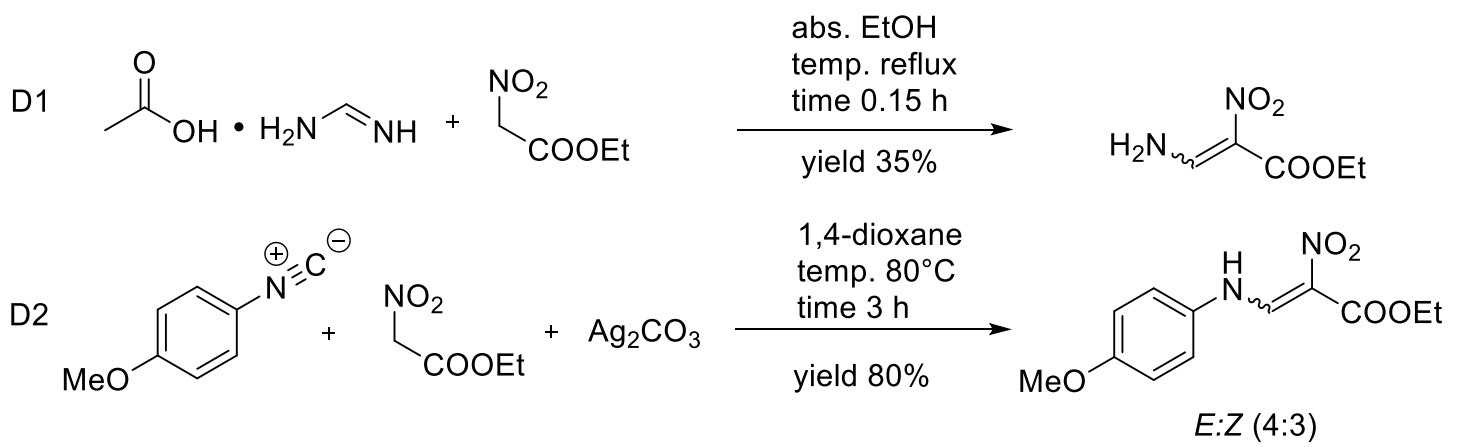

Scheme 5. The preparation of title nitroalkenes by method D. 


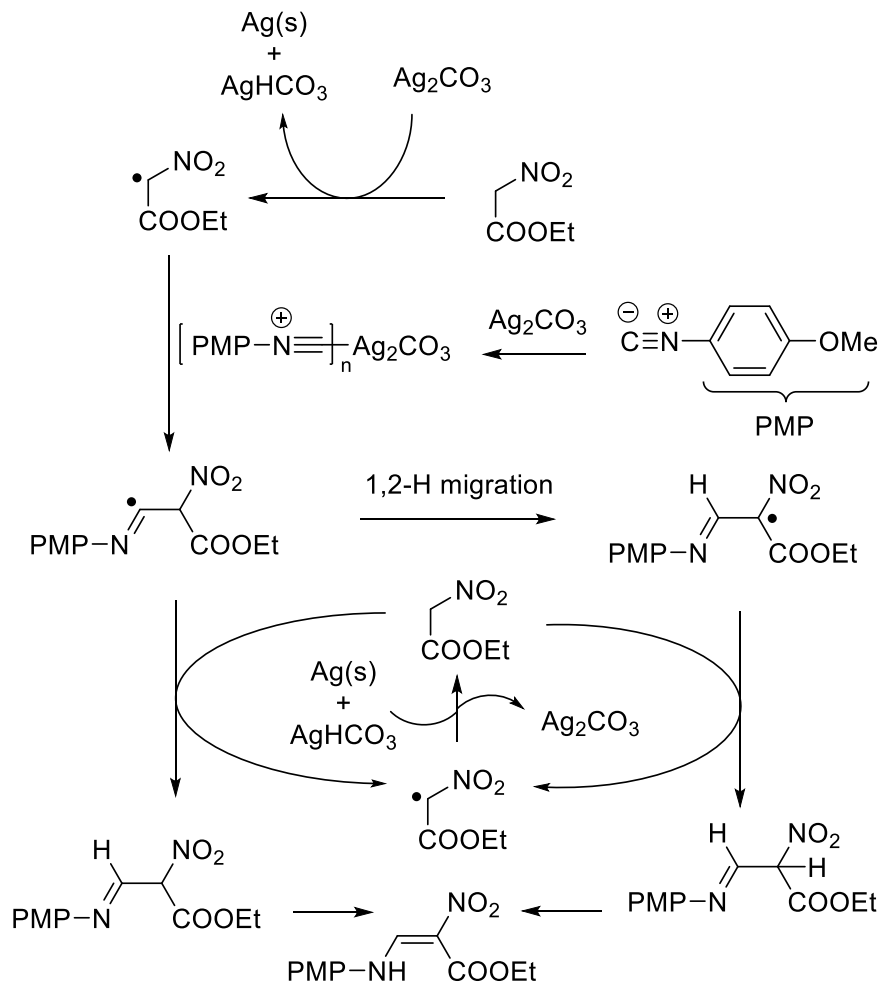

Scheme 6. A plausible mechanism for the second reaction from method D.

\subsection{Utilization in organic synthesis}

Further utilization of the reviewed structures in organic synthesis, known in the literature, can be divided into six groups. Four of these groups contain reactions with nucleophiles via nucleophilic vinylic substitution $\left(S_{N} V\right)$. Widely known reviews have been devoted to mechanistic study ${ }^{49}$ of this reaction and its further utilization for the synthesis of heterocycles. ${ }^{50}$ This paper offers an overview of the reactions of push-pull nitroalkenes with many substrates not only in the $S_{N} V$ reactions but extends the scope to the cycloadditions and miscellaneous reactions.

2.3.1. Reactions with mono-nucleophiles (E). A group of reactions with mono-nucleophiles can be inter- or intramolecular (Scheme 7). These reactions undergo $S_{N} V$ by a single-step or a multistep addition-elimination mechanism ${ }^{51}$ and an inversion of $E / Z$ configuration usually occurs. ${ }^{52}$ All types of nucleophiles $\left(C^{53,54}, N^{29,36,37,55}\right.$, $\mathrm{S}^{16,17}$ ) are known to be utilized in the case of intermolecular reactions. This corresponds to a vast diversity of employed solvents and reaction conditions.

If the starting substrate already contains the second nucleophilic center QHR, which can substitute nucleofuge $X$, an intramolecular reaction occurs to form a ring-fused derivative. ${ }^{45}$ The product of the same ring cyclization can be obtained, if the places of a nucleophile QHR center and leaving group X are switched. ${ }^{43}$ 


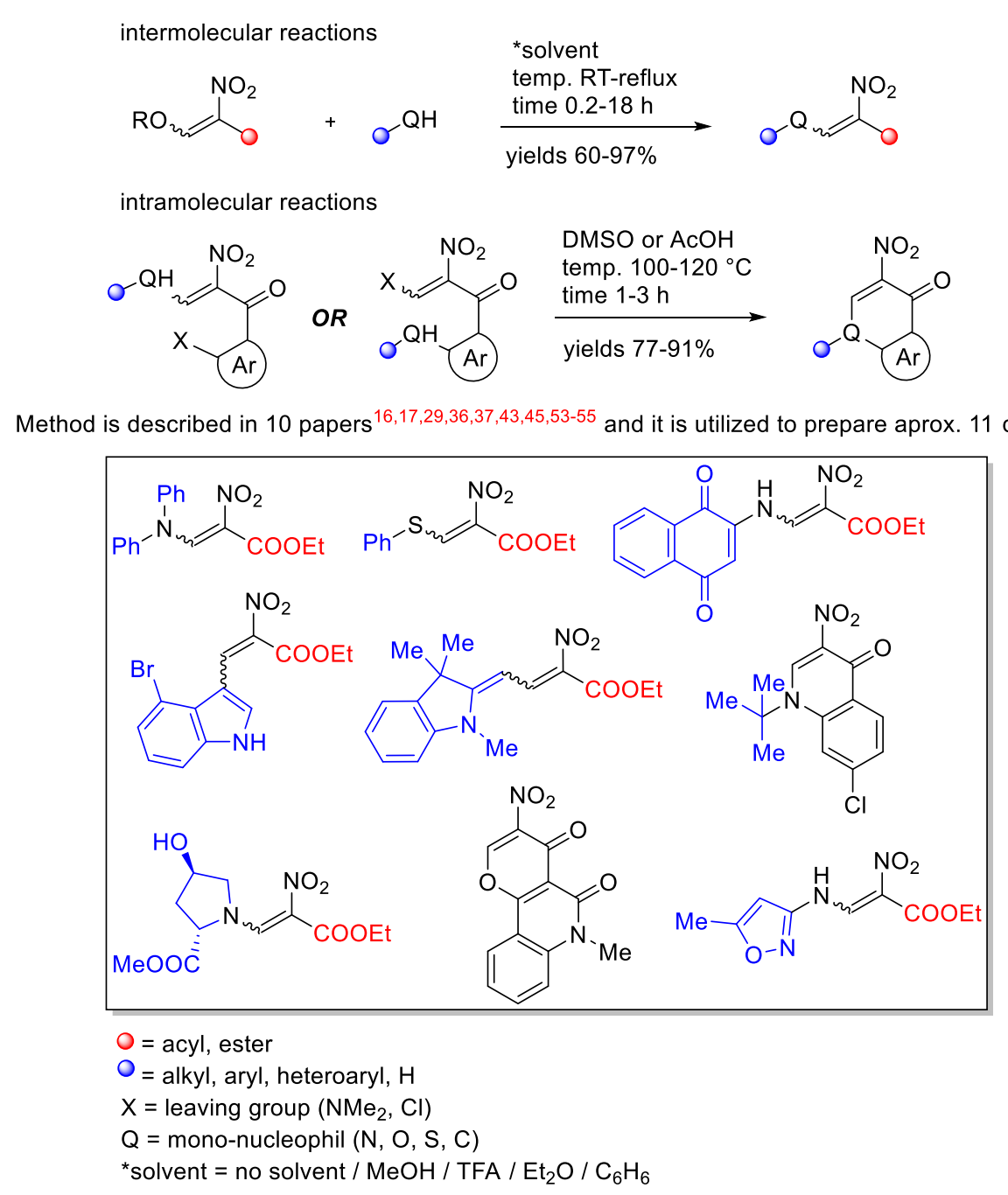

Scheme 7. Overview of reaction reviewed structures with mono-nucleophiles.

2.3.2. Reactions with 1,2-binucleophiles (F). Reactions of 1,2-binucleophiles with title nitroalkenes (Scheme 8) are less frequent in the literature. In reaction $\mathrm{F} 1$, the title compound is combined with hydroxylamine in the presence of pyridine resulting in the salt of the isoxazoline derivative. ${ }^{12}$ Formed isoxazoline salt is used in further synthesis as a source of carbamoyl-substituted nitrile oxide for 1,3-dipolar cycloadditions. ${ }^{30,56}$ Reaction F2 is an example from a set of reactions with hydrazine derivatives that results in pyrazole derivatives. ${ }^{44}$ Generally, the reaction should be composed of two main steps. Frist $S_{N} V$ step results in the substitution of leaving group (OMe or $\mathrm{NMe}_{2}$ ) with one nucleophilic center of 1,2-binucleophile (hydroxylamine or hydrazine derivative). Followed by intramolecular nucleophilic substitution on the carbonyl group (acyl group or methyl ester group) with the second nucleophilic center of 1,2-binucleophile, which forms a five-member heterocyclic ring. However, there are more possible pathways due to the presence of two nucleophilic centers in the unsymmetrically substituted 1,2-binucleophile. The studies of chemo- and regioselectivity rules for the reactions of unsymmetrical 1,2-binucleofiles were conducted only for the conjugated systems, which are structurally similar to title nitroalkenes. ${ }^{57,58}$ 


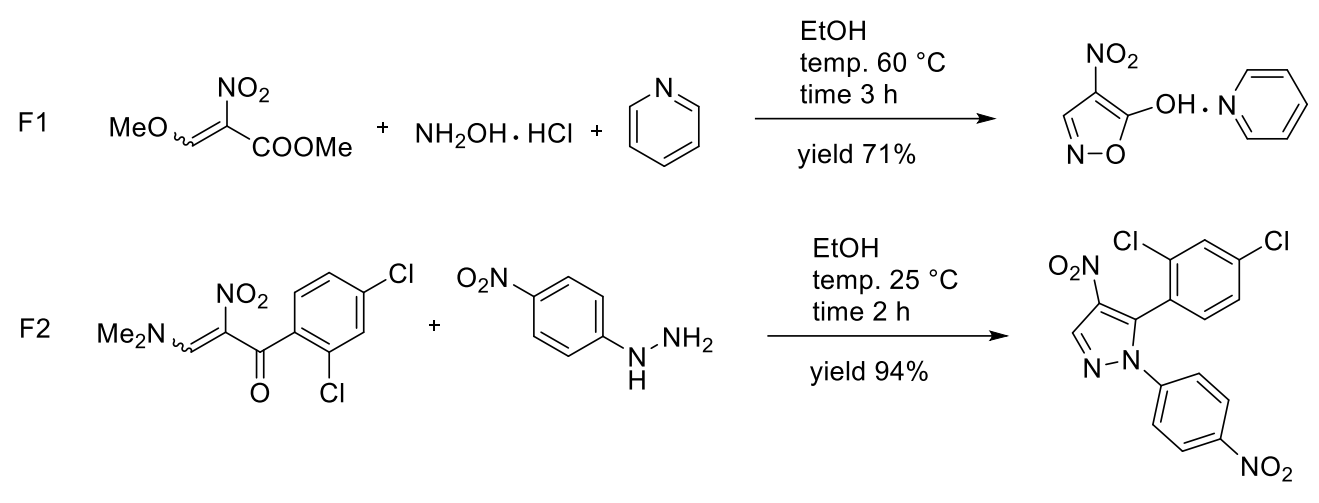

Scheme 8. Overview of reaction reviewed structures with 1,2-binucleophiles.

Authors in the studies of related trisubstituted push-pull olefins concluded that (i) in the case of hydrazine derivatives as 1,2-binucleophiles, the less substituted nitrogen usually reacts first in the $S_{N} V$ step. (ii) In the case of hydroxylamine derivatives, nitrogen heteroatom usually reacts first in the $S_{N} V$ step. (iii) In the case of hydroxylamine derivatives, nitrogen heteroatom usually reacts 1,4-conjugate addition in addition-elimination $\mathrm{S}_{\mathrm{N}} \mathrm{V}$ step. (iv) The direction of the ring closure in the second intramolecular substitution step is substratedependent.

\subsubsection{Reactions with 1,3-binucleophiles (G).}

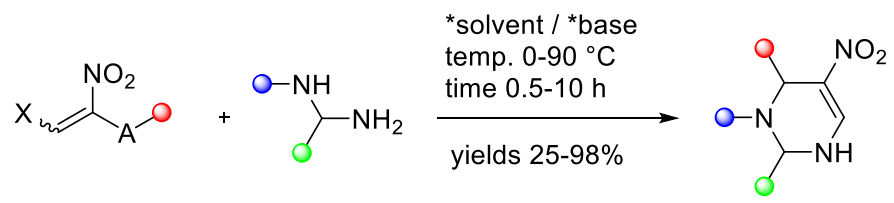

Method is described in 9 papers ${ }^{13-15,18,31,34,35,59-61}$ and it is utilized to prepare aprox. 17 derivatives.

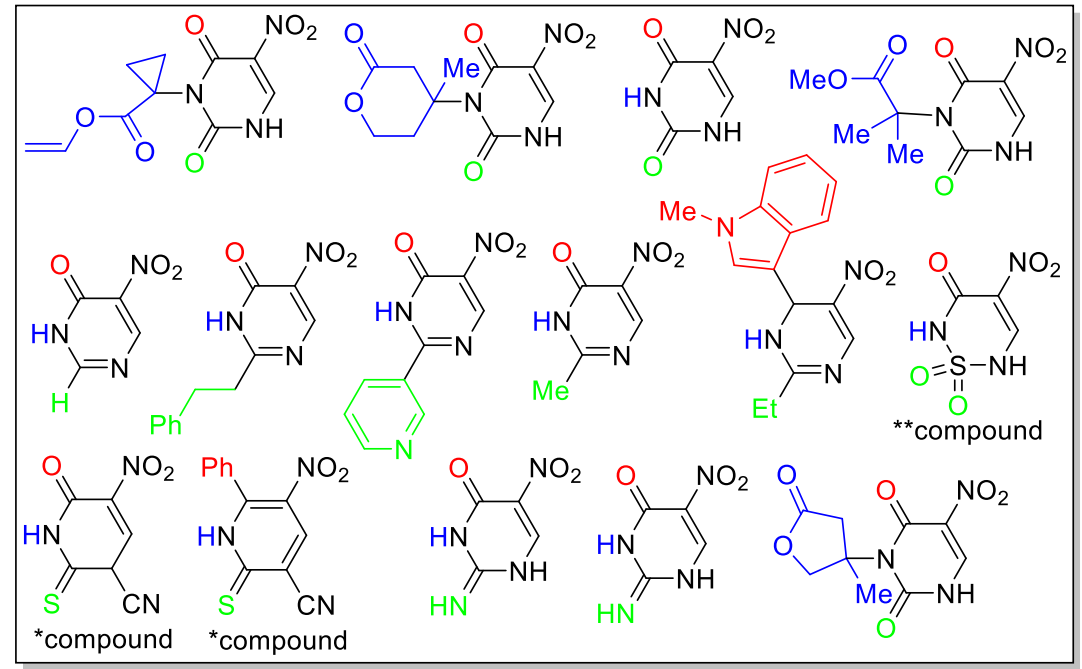

O-A = acyl group, methyl / ethyl ester group

$\mathrm{O}=$ alkyl, heteroaryl, heteroatom, $\mathrm{H}$

$X=$ leaving group (NMe2, NHPh, OMe, OEt)

*solvent $=\mathrm{H}_{2} \mathrm{O} / \mathrm{EtOH} / \mathrm{MeOH} / \mathrm{THF} / \mathrm{MeCN}$

${ }^{*}$ base $=\mathrm{MeONa} / \mathrm{EtOK} / \mathrm{MeOK} / \mathrm{KOH} / \mathrm{K}_{2} \mathrm{CO}_{3} / \mathrm{Cs}_{2} \mathrm{CO}_{3}{ }^{*}$ compund $=$ In this case 1,3-binucleophil is following ethanethioamide: $\mathrm{H}_{2} \mathrm{~N}$
${ }^{*}$

${ }^{* *}$ compound $=\ln$ this case 1,3 -binucleophil is sulfuric diamide.

Scheme 9. Overview of reaction reviewed structures with ureas and amidine derivatives as 1,3-binucleophiles. 


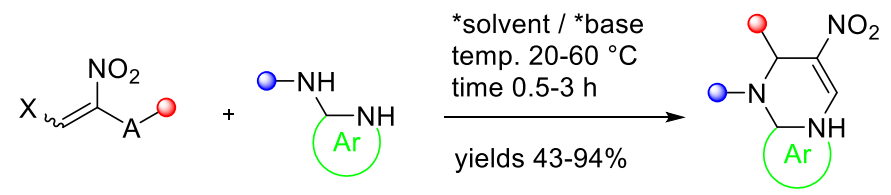

Method is described in 4 papers ${ }^{36,37,62,63}$ and it is utilized to prepare aprox. 4 derivatives.

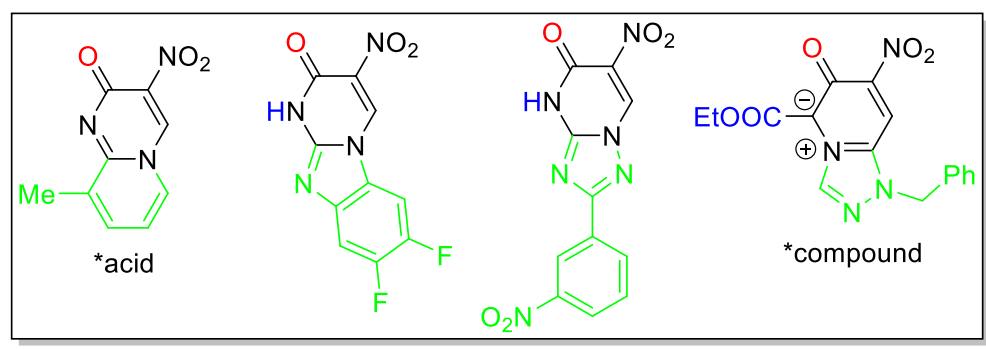

O-A = methyl / ethyl ester group

$\mathrm{O}=$ ethyl ester, $\mathrm{H}$

$X=$ leaving group $\left(\mathrm{NMe}_{2}, \mathrm{OEt}\right)$

*solvent $=$ no solvent $/ \mathrm{EtOH} / \mathrm{PhF}$

*base $=\mathrm{Na}_{2} \mathrm{CO}_{3} / \mathrm{K}_{2} \mathrm{CO}_{3}$

*acid $=$ In this case polyphosphoric acid is used instead of a base.

$\mathrm{EtOOC}-\mathrm{CH}_{2}$

*compound $=$ In this case 1,3-binucleophil is following triazonium salt: $\mathrm{Br}$

Scheme 10. Overview of reaction reviewed structures with heterocycle derivatives as 1,3-binucleophiles.

Articles describing reactions of 1,3-binucleophiles with title nitroalkenes are very frequent in the literature. Therefore, they are divided into two groups based on the structure of the product. The first group contains mostly pyrimidine or pyrimidone derivatives (Scheme 9) that are formed by reactions with ureas and amidines. ${ }^{13-15,18,31,34,59,60}$ There are also examples of other six-membered heterocycles (pyridine ${ }^{35}$ and thiadiazine ${ }^{61}$ ) prepared in a similar manner. The second group contains structurally more different products (Scheme 10) that are formed by reaction with usually amino heterocycles as 1,3-binucleophiles. ${ }^{36,37,62,63}$ The reaction was studied on trisubstituted nitroalkenes with two different nucleophiles ${ }^{35,63}$ (Scheme 11). In both examples, a base was required to form a $C$-nucleophile in the first $S_{N} V$ step. However, in the case of $N$ nucleophiles, the base was required just in the second cyclization step as many of these reactions were performed stepwise with the isolation of the product from the first $S_{N} V$ step.

G1
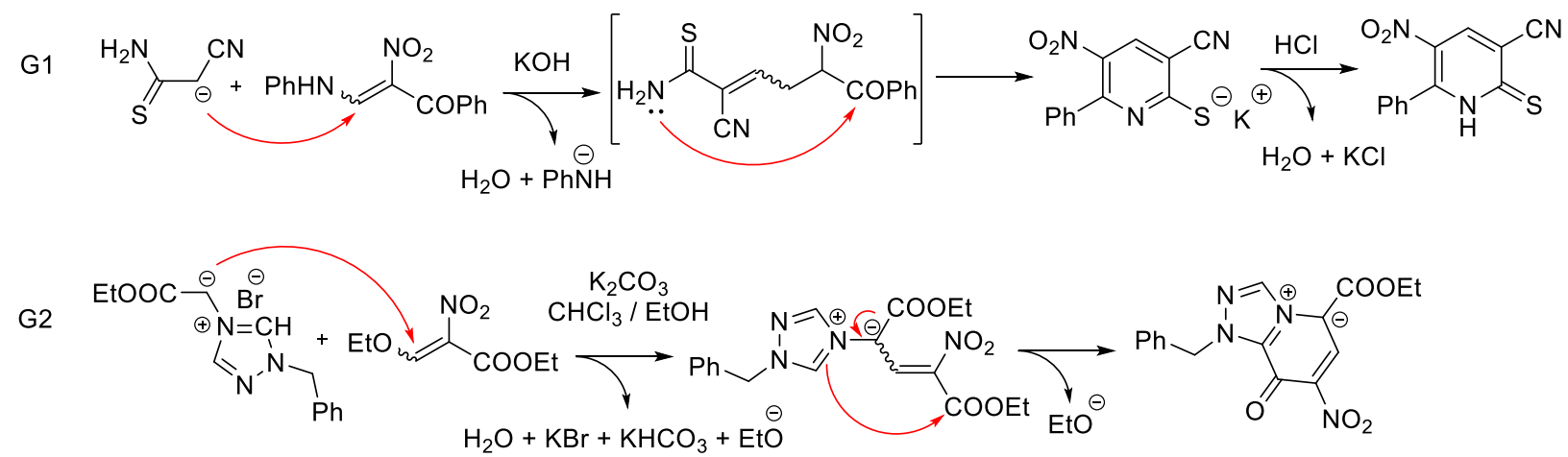

Scheme 11. Reaction steps and intermediates from the studies of the reaction of title nitroalkenes with 1,3binucleophiles. 
2.3.4. Reactions with 1,4-binucleophiles $(\mathbf{H})$. There are very few known reactions of push-pull nitroalkenes with 1,4-binucleophile in the literature. Even more, they are not analogical to other reactions with binucleophiles. Authors ${ }^{64}$ proposed reaction steps (Scheme 12) for the reaction of ethyl 3-ethoxy-2-nitroacrylate with isothiosemicarbazone derivative. The difference from the other 1,4-binucleophiles is the second step that proceeds as another 1,4-addition instead of 1,2-addition. Due to this change in the second reaction step, a 5membered heterocycle is formed instead of 7-membered one. In this case, nitroalkene is fragmented and it acts as a donor of the methylidene group.

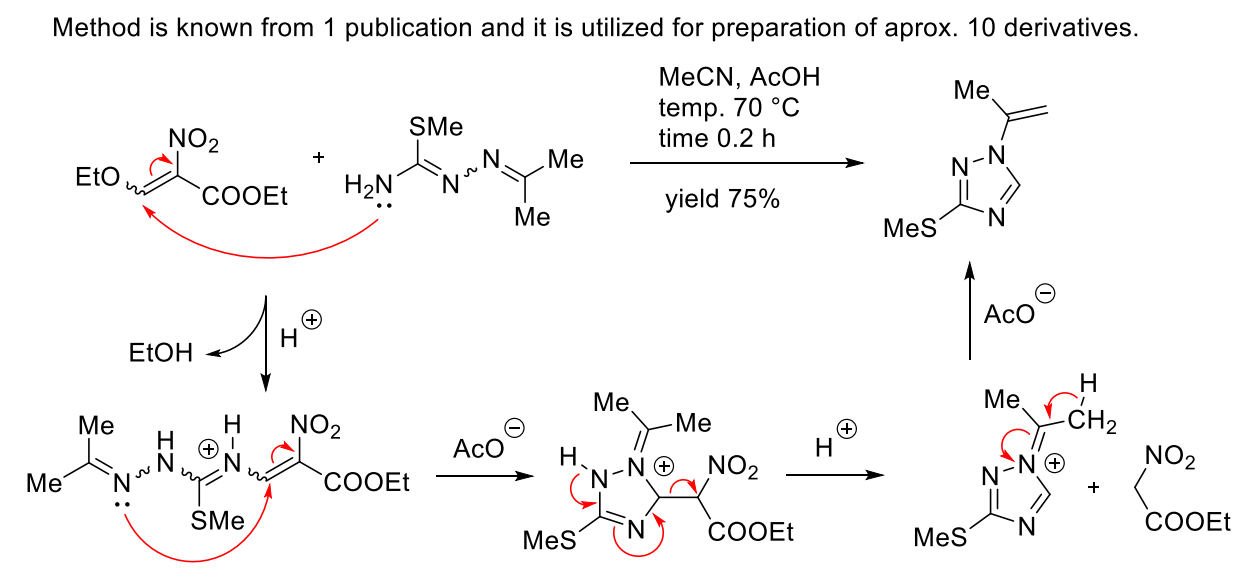

Scheme 12. The pathway and reaction of reviewed nitroalkene with 1,4-binucleophile.

2.3.5. Pericyclic reactions $(\mathrm{J})$. Title structures were utilized in three different types of cycloadditions (Scheme 13). In the first reaction (J1) is prepared conformationally constrained cysteine analog by [4+2] Diels-Alder cycloaddition. ${ }^{16}$ Nitroalkene acts as a dienophile in this reaction. The authors confirmed the presence and difference in yield of all four possible exo/endo products by exploiting different $E / Z$ mixtures of the starting nitroalkene. In the second reaction (J2) trans-fused bicyclic nitronate is prepared by tandem transetherification-intramolecular hetero [4+2] Diels-Alder reaction. ${ }^{65}$ In this case, nitroalkene acts as heterodiene. The authors suggested a reaction pathway for this tandem reaction (Scheme 14).

Third reaction (J3) originates from the study of the single electron transfer (SET) pathway in the [3+2] cycloaddition of dipolar trimethylenemethane with olefins. ${ }^{66}$ However, in the case of ethyl 3-ethoxy-2nitroacrylate was not obtained expected exomethylene cycloadduct due to the cleavage on silica gel during the chromatography purification. The fourth reaction (J4) comes from series, which describes the regioselective synthesis of nitroarenes based on [3+3] cyclocondensations of 1,3-bis(silyloxy)-1,3-butadienes. ${ }^{25}$ 


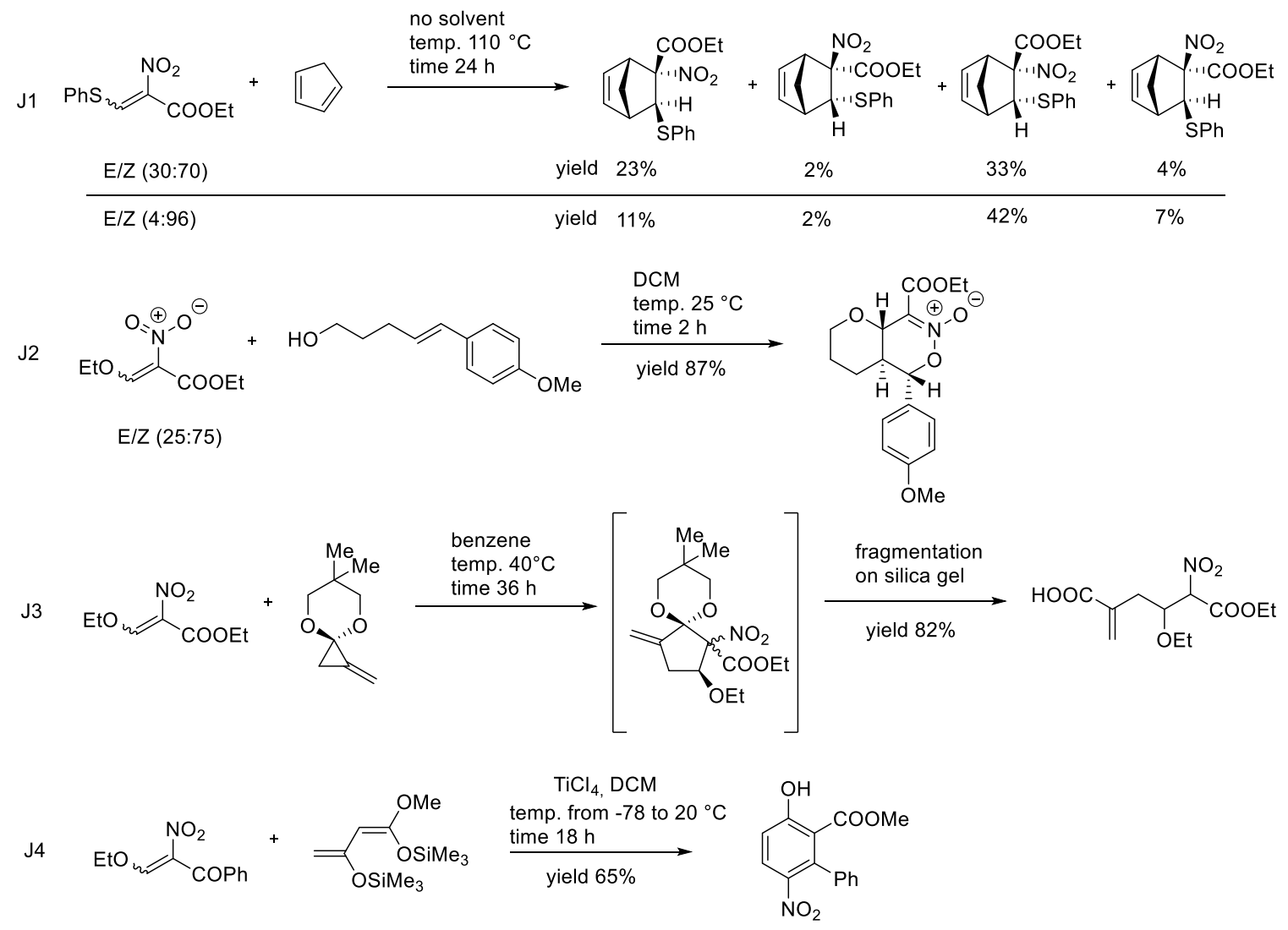

Scheme 13. Overview of reactions title nitroalkenes in pericyclic reactions.

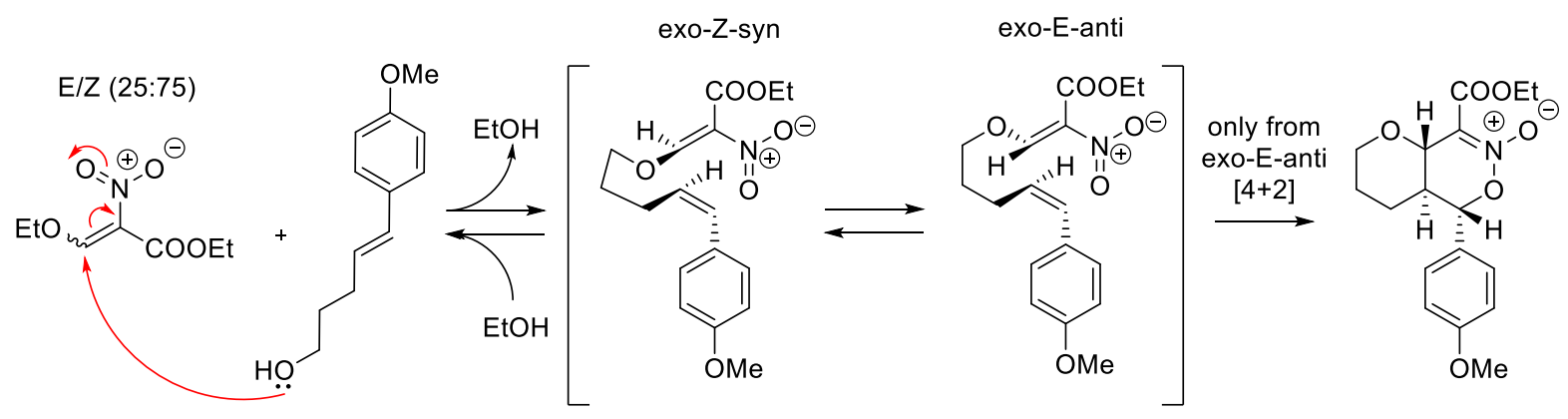

Scheme 14. Proposed reaction pathway for pericyclic reaction J2.

2.3.6. Miscellaneous utilization in organic synthesis (K). The last group of reactions summarizes examples from the literature, which systematically does not fit any of the previous chapters (Scheme 15). Nitroalkenes in these reactions provided unexpected products. In the first reaction (K1) could be expected $S_{N} V$ product, however, nitroalkene is fragmented during the reaction, and oxime derivative is formed. ${ }^{67}$ The authors proposed a mechanism for such a fragmentation (Scheme 16). 


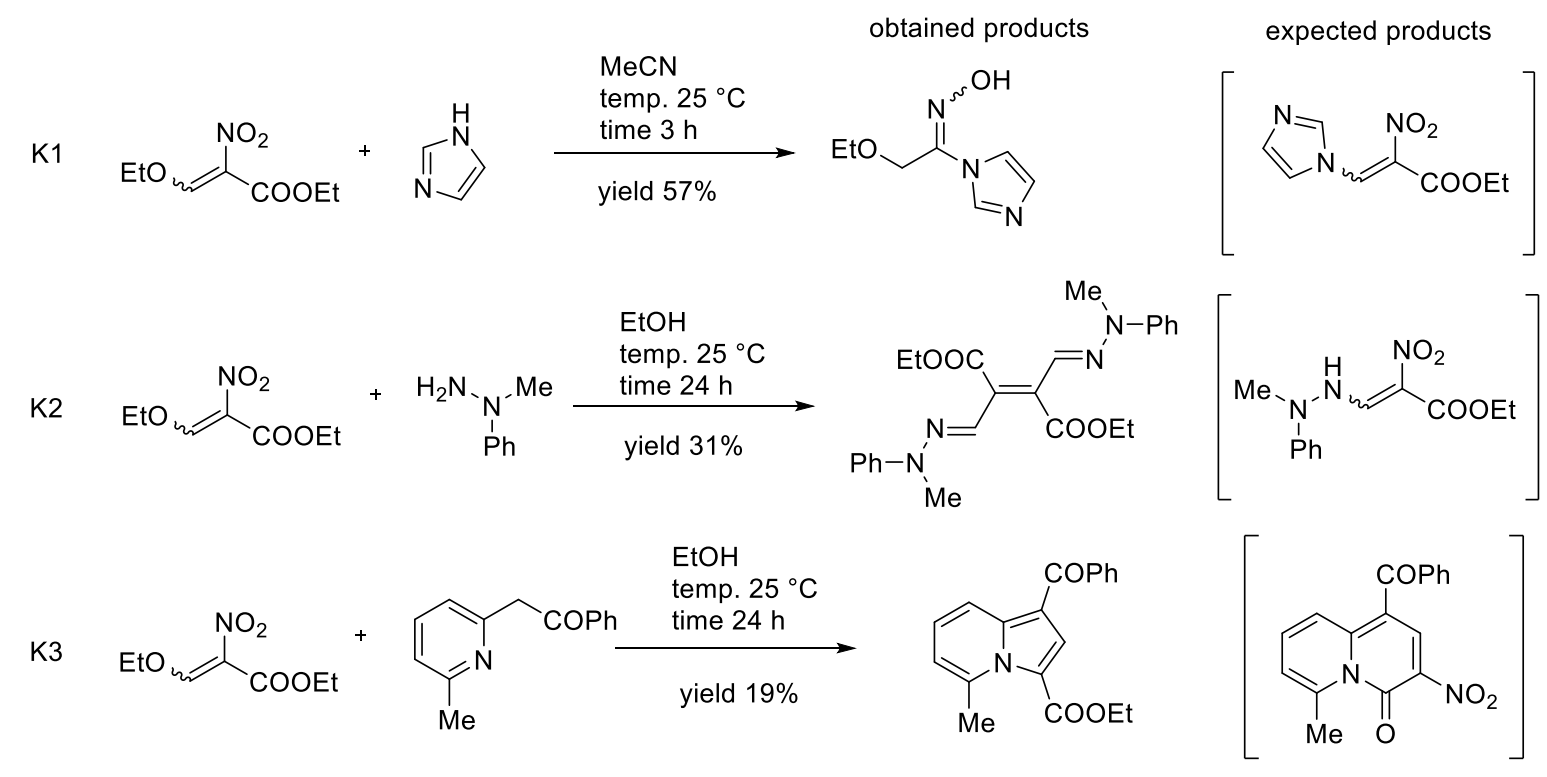

Scheme 15. Overview of miscellaneous reactions of reviewed structures.

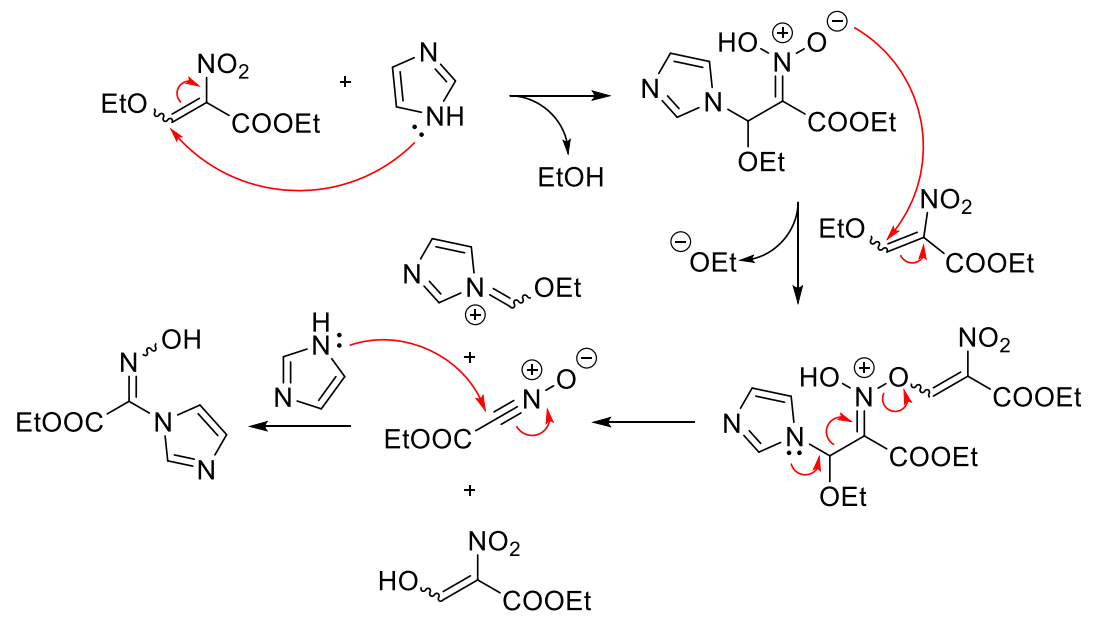

Scheme 16. A plausible mechanism for the reaction of ethyl 3-ethoxy-2-nitroacrylate with imidazole.

In the second reaction (K2) could be also expected $S_{N} V$ product, however, a dimer is formed. This structure is published as a crystallographic report. ${ }^{68}$ Third reaction (K3) is part of the study about a quinolizone formations. However, in the case of ethyl 3-ethoxy-2-nitroacrylate, an indolizine derivative is formed. ${ }^{69}$

\section{Conclusions}

This review summarizes the chemistry of trisubstituted push-pull nitroalkenes. It discusses the importance of this group of nitroalkenes in organic synthesis with emphasis on their utilization in the preparation of biologically active compounds. Individual chapters treat physical and chemical properties in terms of $E / Z$ isomerism, preparation, and further utilization in organic synthesis. Isomerism studies stated that $Z$ - isomer should be the predominant one in the case of alkyl 3-amino-2-nitroacrylates due to the intramolecular 
hydrogen bond between amino hydrogen and oxygen of the nitro group. However, the presence of the pushpull system with nitro group results in fast isomerization, and a mixture of $E / Z$ - isomers could be obtained even in the solid state. There are 5 published methods of the preparation of these nitroalkenes. Most relevant of them could be generalized as reactions of the nitro compound with active methylene group, such as ethyl nitroacetate, with C-electrophile that contains at least two leaving groups, for instance, triethyl orthoformate. Utilization in the organic synthesis of these nitroalkenes is much more versatile. In the literature are known examples of the reactions with mononucleophiles, resulting in $\mathrm{S}_{\mathrm{N}} \mathrm{V}$ products, and binucleophiles, resulting in a vast range of the five- / six-membered heterocycles / fused heterocycles. Generally, they should be regarded as bifunctional electrocyclophiles with three carbon fragments for the target molecule. Reviewed nitroalkenes can be utilized in [4+2] Diels-Alder cycloadditions as heterodienes or dienophiles. There are examples of other types of pericyclic reactions $([3+2],[3+3])$ exploiting these nitroalkenes as well. Overall, this review should simplify an incorporation of reviewed nitroalkenes into the future synthetic approaches by outlining the most relevant results from the studies about them, known in the literature up to 2020.

\section{Acknowledgements}

This work was financially supported by the Science and Technology Assistance Agency under contract No. APVV-17-0513. The author (BP) would like to thank for the financial contribution from the STU Grant scheme for Support of Young Researchers.

\section{References}

1. Molander, G. A., Trost, B. M., Abramite, J. A., Arrayás, R. G., Avilov, D., Block, E., Carretero, J. C., Collier, S. J., Dittmer, D., Drabowicz, J., Gaumont, A.-C., Gulea, M., Jubault, P., Keglevich, G., Kiełbasiński, P., Leclerc, E., Mclaws, M. D., Mikołajczyk, M., Ono, N., Quirion, J.-C., Reissig, H.-U., Sammakia, T., Sammons, M. F., Szelke, H., Zimmer, R. In Houben-Weyl Methods of Molecular Transformations, Eds.; Georg Thieme Verlag: Stuttgart, 2013; pp 337-370. https://dx.doi.org/10.1055/sos-sd-033-00001

2. Barrett, A. G. M. Chem. Soc. Rev. 1991, 20, 95-127. https://dx.doi.org/10.1039/CS9912000095

3. Barrett, A. G. M.; Graboski, G. G. Chem. Rev. 1986, 86, 751-762. https://dx.doi.org/10.1021/cr00075a002

4. Berner, O. M.; Tedeschi, L.; Enders, D. Eur. J. Org. Chem. 2002, 2002, 1877-1894. https://dx.doi.org/10.1002/1099-0690(200206)2002:12\%3C1877::AID-EJOC1877\%3E3.0.CO;2-U

5. Ono, N. The Nitro Group in Organic Synthesis, Eds.; John Wiley \& Sons, Inc.: New York, 2001. https://dx.doi.org/10.1002/0471224480

6. Nef, J. Justus Liebigs Ann. Chem. 1894, 280, 263-291. https://dx.doi.org/10.1002/jlac.18942800209

7. Formenti, D.; Ferretti, F.; Scharnagl, F. K.; Beller, M. Chem. Rev. 2019, 119, 2611-2680. https://dx.doi.org/10.1021/acs.chemrev.8b00547

8. Tanner, D. D.; Blackburn, E. V.; Diaz, G. E. J. Am. Chem. Soc. 1981, 103, 1557-1559. https://dx.doi.org/10.1021/ja00396a044 
9. Ferreira, A. M.; Trostchansky, A.; Ferrari, M.; Souza, J. M.; Rubbo, H. In Methods in Enzymology, Eds.; Academic Press Inc., 2008; pp 33-51.

https://dx.doi.org/10.1016/S0076-6879(08)01203-2

10. Halimehjani, A. Z.; Namboothiri, I. N. N.; Hooshmand, S. E. RSC Adv. 2014, 4, 48022-48084. https://dx.doi.org/10.1039/c4ra08828j

11. Halimehjani, A. Z.; Namboothiri, I. N. N.; Hooshmand, S. E. RSC Adv. 2014, 4, 31261-31299. https://dx.doi.org/10.1039/c4ra04069d

12. Nishiwaki, N.; Takada, Y.; Inoue, Y.; Tohda, Y.; Ariga, M. J. Heterocycl. Chem. 1995, 32, 473-475. https://dx.doi.org/10.1002/jhet.5570320215

13. de la Cuesta, E.; Avendaño, C. J. Heterocycl. Chem. 1985, 22, 337-339. https://dx.doi.org/10.1002/ihet.5570220222

14. Fournier, J. F.; Clary, L.; Chambon, S.; Dumais, L.; Harris, C. S.; Millois, C.; Pierre, R.; Talano, S.; Thoreau, É.; Aubert, J.; Aurelly, M.; Bouix-Peter, C.; Brethon, A.; Chantalat, L.; Christin, O.; Comino, C.; El-Bazbouz, G.; Ghilini, A. L.; Isabet, T.; Lardy, C.; Luzy, A. P.; Mathieu, C.; Mebrouk, K.; Orfila, D.; Pascau, J.; Reverse, K.; Roche, D.; Rodeschini, V.; Hennequin, L. F. J. Med. Chem. 2018, 61, 4030-4051. https://dx.doi.org/10.1021/acs.jmedchem.8b00067

15. Cui, G.; Jin, J.; Chen, H.; Cao, R.; Chen, X.; Xu, B. Bioorganic Med. Chem. 2018, 26, 2186-2197. https://dx.doi.org/10.1016/j.bmc.2018.03.024

16. Ruffoni, A.; Casoni, A.; Pellegrino, S.; Gelmi, M. L.; Soave, R.; Clerici, F. Tetrahedron 2012, 68, $1951-1962$. https://dx.doi.org/10.1016/j.tet.2011.12.052

17. Ruffoni, A.; Ferri, N.; Bernini, S. K.; Ricci, C.; Corsini, A.; Maffucci, I.; Clerici, F.; Contini, A. J. Med. Chem. 2014, 57, 2953-2962.

https://dx.doi.org/10.1021/im401924s

18. Agarwal, P. K.; Dathi, M. D.; Saifuddin, M.; Kundu, B. Beilstein J. Org. Chem. 2012, 8, 1901-1908. https://dx.doi.org/10.3762/bjoc.8.220

19. Brimble, M. A.; Rowan, D. D. J. Chem. Soc. Perkin Trans. 1 1990, 2, 311-314. https://dx.doi.org/10.1039/p19900000311

20. Bach, J.; Eastwood, P.; González, J.; Gómez, E.; Alonso, J. A.; Fonquerna, S.; Lozoya, E.; Orellana, A.; Maldonado, M.; Calaf, E.; Albertí, J.; Pérez, J.; Andrés, A.; Prats, N.; Carreño, C.; Calama, E.; De Alba, J.; Calbet, M.; Miralpeix, M.; Ramis, I. J. Med. Chem. 2019, 62, 9045-9060.

https://dx.doi.org/10.1021/acs.jmedchem.9b00533

21. Chiara, J. L.; Gómez-Sánchez, A.; Hidalgo, F. J.; Bellanato, J. J. Chem. Soc. Perkin Trans. 2 1988, 9, 16911698. https://dx.doi.org/10.1039/P29880001691

22. Reuben, J. J. Am. Chem. Soc. 1986, 108, 1735-1738. https://dx.doi.org/10.1021/ja00268a003

23. Reuben, J. J. Am. Chem. Soc. 1987, 109, 316-321. https://dx.doi.org/10.1021/ja00236a004

24. Michalik, M. Zeitschrift für Chemie 2010, 25, 287-288. https://dx.doi.org/10.1002/zfch.19850250805

25. Riahi, A.; Shkoor, M.; Fatunsin, O.; Yawer, M. A.; Hussain, I.; Fischer, C.; Langer, P. Tetrahedron 2009, 65, 9300-9315. https://dx.doi.org/10.1016/j.tet.2009.09.014

26. Jones, R. G. J. Am. Chem. Soc. 1951, 73, 3684-3686. 
https://dx.doi.org/10.1021/ja01152a034

27. Tikhonova, N. A.; Babievskii, K. K.; Belikov, V. M. Bull. Acad. Sci. USSR Div. Chem. Sci. 1967, 16, $842-844$. https://dx.doi.org/10.1007/BF00915668

28. Kamlet, M. J. J. Org. Chem. 1959, 24, 714-715. https://dx.doi.org/10.1021/jo01087a615

29. Marcos, A.; Pedregal, C.; Avendaño, C. Tetrahedron 1994, 50, 12941-12952. https://dx.doi.org/10.1016/S0040-4020(01)81213-8

30. Nishiwaki, N.; Kobiro, K.; Hirao, S.; Sawayama, J.; Saigo, K.; Ise, Y.; Nishizawa, M.; Ariga, M. Org. Biomol. Chem. 2012, 10, 1987-1991.

https://dx.doi.org/10.1039/c2ob06925c

31. Prystaš, M.; Gut, J. Collect. Czechoslov. Chem. Commun. 1963, 28, 2501-2509. https://dx.doi.org/10.1135/cccc19632501

32. Tamura, M.; Ise, Y.; Okajima, Y.; Nishiwaki, N.; Ariga, M. Synthesis (Stuttg). 2006, 2006, 3453-3461. https://dx.doi.org/10.1055/s-2006-950210

33. Claisen, L. Berichte der Dtsch. Chem. Gesellschaft 1893, 26, 2729-2735. https://dx.doi.org/10.1002/cber.18930260375

34. Boiteau, J. G.; Bouix-Peter, C.; Chambon, S.; Clary, L.; Daver, S.; Dumais, L.; Fournier, J. F.; Harris, C. S.; Mebrouk, K.; Millois, C.; Pierre, R.; Rodeville, N.; Talano, S.; Tomas, L. Tetrahedron Lett. 2016, 57, 23672371.

https://dx.doi.org/10.1016/j.tetlet.2016.04.039

35. Chunikhin, K. S.; Rodinovskaya, L. A.; Shestopalov, A. M. Russ. Chem. Bull. 2003, 52, 447-450. https://dx.doi.org/10.1023/A:1023483521652

36. Wolfbeis, O. S. Chem. Ber. 1977, 110, 2480-2493.

https://dx.doi.org/10.1002/cber.19771100708

37. Wolfbeis, O. S. Chem. Ber. 1981, 114, 3471-3484. https://dx.doi.org/10.1002/cber.19811141102

38. McConkey, G. A.; Bedingfield, P. T. P.; Burrell, D. R.; Chambers, N. C.; Cunningham, F.; Prior, T. J.; Fishwick, C. W. G.; Boa, A. N.; Bioorganic Med. Chem. Lett. 2017, 27, 3878-3882.

https://dx.doi.org/10.1016/j.bmcl.2017.06.052

39. Bergmann, W.; Johnson, T. B. Berichte der Dtsch. Chem. Gesellschaft (A B Ser.) 1933, 66, 1492-1496. https://dx.doi.org/10.1002/cber.19330661009

40. Buerger, L. R.; Johnson, T. B. J. Am. Chem. Soc. 1934, 56, 2754-2755.

https://dx.doi.org/10.1021/ja01327a072

41. Whitehead, C. W. J. Am. Chem. Soc. 1953, 75, 671-675.

https://dx.doi.org/10.1021/ja01099a047

42. Inoshita, T.; Goshi, K.; Morinaga, Y.; Umeda, Y.; Ishikawa, H. Org. Lett. 2019, 21, 2903-2907. https://dx.doi.org/10.1021/acs.orglett.9b00932

43. Maslova, M. M.; Marchenko, N. B.; Glushkov, R. G. Pharm. Chem. J. 1991, 25, 657-660. https://dx.doi.org/10.1007/BF00777692

44. Maslova, M. M.; Pol'shakov, V. I.; Anisimova, O. S.; Marchenko, N. B.; Glushkov, R. G. Pharm. Chem. J. 1993, 26, 889-893.

https://dx.doi.org/10.1007/BF00767668

45. Morsy, J. M.; Hassanin, H. M.; Ismail, M. M.; Abd-Alrazk, M. M. A. J. Chem. Res. 2016, 40, 239-246. https://dx.doi.org/10.3184/174751916X14579598972166 
46. Liu, J.; Liu, Z.; Liao, P.; Zhang, L.; Tu, T.; Bi, X. Angew. Chemie Int. Ed. 2015, 54, 10618-10622. https://dx.doi.org/10.1002/10.1002/anie.201504254

47. Zhang, B.; Studer, A. Chem. Soc. Rev. 2015, 44, 3505-3521. https://dx.doi.org/10.1039/c5cs00083a

48. Millich, F. Chem. Rev. 1972, 72, 101-113. https://dx.doi.org/10.1021/cr60276a001

49. Rappoport, Z. Adv. Phys. Org. Chem. 1969, 7, 1-114. https://dx.doi.org/10.1016/S0065-3160(08)60263-4

50. Litvinov, V. P.; Yakunin, Y. Y.; Dyachenko, V. D. Chem. Heterocycl. Compd. 2001, 37, 37-76. https://dx.doi.org/10.1023/A:1017536700235

51. Rappoport, Z. Acc. Chem. Res. 1981, 14, 7-15. https://dx.doi.org/10.1021/ar00061a002

52. Saloň, J.; Milata, V.; Gatial, A.; Prónayová, N.; Leško, J.; Černuchová, P.; Rappoport, Z.; Vo-Thanh, G.; Loupy, A. European J. Org. Chem. 2005, 2005, 4870-4878. https://dx.doi.org/10.1002/ejoc.200500298

53. Forzato, C.; Felluga, F.; Nitti, P.; Pitacco, G.; Valentin, E. Arkivoc 2002, 2002, 236-248. https://dx.doi.org/10.3998/ark.5550190.0003.b21

54. Horwell, D. C.; Nichols, P. D.; Ratcliffe, G. S.; Roberts, E. J. Org. Chem. 1994, 59, 4418-4423. https://dx.doi.org/10.1021/jo00095a015

55. Wurz, R. P. In Encyclopedia of Reagents for Organic Synthesis, Eds.; John Wiley \& Sons, Ltd, 2011. https://dx.doi.org/10.1002/047084289x.rn01278

56. Nishiwaki, N.; Kobiro, K.; Hirao, S.; Sawayama, J.; Saigo, K.; Ise, Y.; Okajima, Y.; Ariga, M. Org. Biomol. Chem. 2011, 9, 6750-6754.

57. Černuchová, P.; Vo-Thanh, G.; Milata, V.; Loupy, A.; Jantová, S.; Theiszová, M. Tetrahedron 2005, 61, 53795387.

https://dx.doi.org/10.1016/j.tet.2005.03.066

58. Domínguez, E.; Ibeas, E.; De Marigorta, E. M.; Palacios, J. K.; SanMartín, R. J. Org. Chem. 1996, 61, 54355439.

https://dx.doi.org/10.1021/jo960024h

59. Chambon, S.; Talano, S.; Millois, C.; Dumais, L.; Pierre, R.; Tomas, L.; Mathieu, C.; Ghilini, A. L.; Vanthuyne, N.; Reverse, K.; Brethon, A.; Rodeschini, V.; Comino, C.; Mouis, G.; El-Bazbouz, G.; Clary, L.; Fournier, J. F.; Bouix-Peter, C.; Harris, C. S.; Hennequin, L. F. Tetrahedron 2018, 74, 4805-4822.

https://dx.doi.org/10.1016/i.tet.2018.07.029

60. Harcken, C.; Riether, D.; Kuzmich, D.; Liu, P.; Betageri, R.; Ralph, M.; Emmanuel, M.; Reeves, J. T.; Berry, A.; Souza, D.; Nelson, R. M.; Kukulka, A.; Fadra, T. N.; Zuvela-Jelaska, L.; Dinallo, R.; Bentzien, J.; Nabozny, G. H.; Thomson, D. S. J. Med. Chem. 2014, 57, 1583-1598.

https://dx.doi.org/10.1021/jm4019178

61. Goya, P.; Stud, M. J. Heterocycl. Chem. 1978, 15, 253-256.

https://dx.doi.org/10.1002/jhet.5570150214

62. Fedotov, V. V.; Ulomskiy, E. N.; Gorbunov, E. B.; Eltsov, O. S.; Voinkov, E. K.; Savateev, K. V.; Drokin, R. A.; Kotovskaya, S. K.; Rusinov, V. L. Chem. Heterocycl. Compd. 2017, 53, 582-588.

https://dx.doi.org/10.1007/s10593-017-2095-8

63. Matsuda, Y.; Chiyomaru, Y.; Motokawa, C.; Nishiyori, T. Heterocycles 1995, 41, 329-336. https://dx.doi.org/10.3987/COM-94-6950 
64. Yamazaki, C.; Takahashi, T.; Hata, K. J. Chem. Soc. Perkin Trans. 1 1988, 7, 1897.

https://dx.doi.org/10.1039/p19880001897

65. Wada, E.; Yoshinaga, M. Tetrahedron Lett. 2004, 45, 2197-2201.

https://dx.doi.org/10.1016/i.tetlet.2004.01.026

66. Yamago, S.; Ejiri, S.; Nakamura, M.; Nakamura, E. J. Am. Chem. Soc. 1993, 115, 5344-5345.

https://dx.doi.org/10.1021/ja00065a076

67. Hartman, G. D.; Hartman, R. D. J. Heterocycl. Chem. 1984, 21, 1907-1908.

https://dx.doi.org/10.1002/jhet.5570210666

68. Liu, P.; Yuan, L.; Song, X.; Yan, H. Acta Crystallogr. Sect. E Struct. Reports Online 2014, 70, 723-723. https://dx.doi.org/10.1107/S1600536814011970

69. Thyagarajan, B. S.; Gopalakrishnan, P. V. Tetrahedron 1965, 21, 3305-3309.

https://dx.doi.org/10.1016/S0040-4020(01)96952-2

\section{Authors' Biographies}

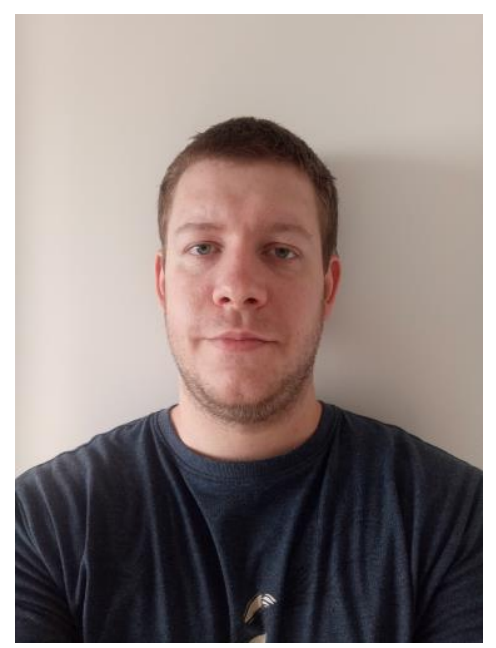

Branislav Pavilek is a Ph.D. student from the Faculty of Chemical and Food Technology of the Slovak University of Technology. He graduated in organic chemistry at the same institution in 2018. He stayed at the research site of Syngenta Crop Protection AG in 2020. His research is focused on the synthesis and functionalization of five-membered heterocyclic compounds and their fused analogs, thiophenes, benzodithiophenes, isoxazoles, pyrazoles, and the development of novel application in organic chemistry for these molecules. 


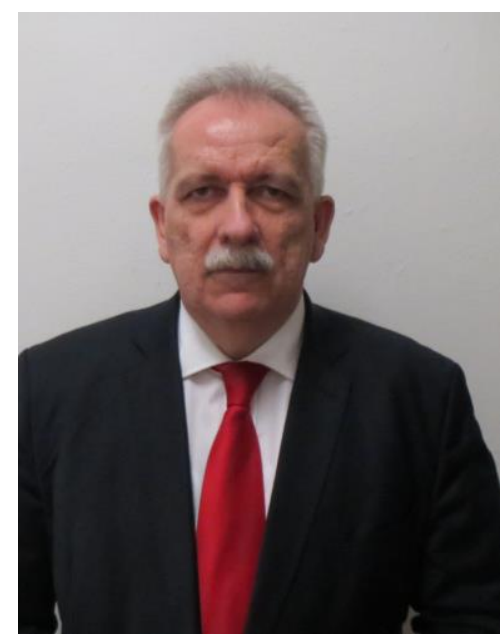

Viktor Milata graduated in Organic Chemistry from the Faculty of Chemical and Food Technology of the Slovak University of Technology in 1981, he received Ph.D. in 1987. In 1996 he obtained Assoc. Prof. title, in 2009 DSc. in Pharmaceutical Chemistry and 2010 full professor of Organic Chemistry. He stayed at UNED Madrid (1999-2000), University Cambridge (8/1995), University Paris-Orsay (1992-2008, 10 months), and Technical University Vienna (1993-2008, 9 months). His research focuses on heterocyclic compounds, tautomerism, benzoxazole, quinoxalines, quinolones, triazines, dihydropyridines, enolethers, nitro- and aminoderivatives, spectral properties, and development and applications of new methodologies in organic synthesis. 